\title{
MICE Tourism in Egypt: Opportunities and challenges
}

\section{Jermien Hussein Abdelkafy}

Tourism Studies Department

Faculty of Tourism \& Hotel Management

Helwan University
Doaa Samir Mohammed Hizah

Tourism Studies Department

Faculty of Tourism \& Hotels

Mansoura University

\begin{abstract}
:
The term MICE refers to meetings, incentives, conventions and exhibitions, it is a significant type of tourism in which large groups are brought together for particular purposes. The MICE industry is growing and maturing at a rapid rate, it is recognized as a sector that draws direct and indirect revenue to host destinations, creates employment opportunities and generates foreign exchange.
\end{abstract}

The core problem of this paper is to know the reasons of: The low proportion of MICE tourism in Egypt compared with MICE tourism movement all over the world, the insufficient marketing efforts for MICE tourism, as well as lack of travel agencies' awareness of its importance.

The overall goal of this paper is to: a) discuss the growth of the MICE tourism Sector , b) analyze MICE tourism resources in Egypt, c) make a SWOT analysis, Strength, Weakness, Opportunity and Threat, of Egypt as a MICE tourism destination, f) identify challenges facing travel agencies in Egypt to organize MICE tourism programs.

This paper is built on the following hypothesis; Egypt resources as a MICE tourism destination haven't exploited ideally yet.

The method of research was based on survey questionnaires distributed to Tourism and MICE experts in Egypt (September 2016: November 2016). Data interpretation was performed in SPSS. V.15. Relevant recommendations are made.

Key words: MICE Tourism; Egypt's image and position as a MICE destination;

\section{Introduction}

The term "MICE" in the context of travel refers to Meetings, Incentives, Conferences/ Conventions and Exhibitions/ Events (Lin and Chen, 2014). It is a type of tourism in which specialized groups are dedicated to planning, booking and facilitating conferences, seminars and other events in advance. It includes a wellplanned agenda focusing on a particular theme. The components of MICE tourism include corporate meeting planners; meetings and convention departments of hotels and resorts, exhibition and convention centers; conference cruise ships; food and beverage managers; entertainment companies; logistics firms; private tour operators and transfer companies; incentive houses; professional trade organizations; tourism boards; airlines; business centers; consulting companies; insurance companies; tourism trade associations and travelselling professionals (Khan, 2015). The locations of MICE events are usually chosen by specialized convention agencies in particular countries and cities, the process of marketing and choosing is mostly conducted in advance of the event, as holding major events can benefit the local economy of the host destination (Smith and Stewart, 2014).

\section{1- The Significance of MICE Tourism}

Besides its large number of delegates, MICE tourism generates large expenditure to the national economy as delegates spend more time and money compared to leisure tourists (Wan, 2011). It brings many profits for other related industries like transportation, accommodation, entertainment, advertising and leisure (Ratajczak-Mrozek, 2014), beside creating a lot of business opportunities within the tourism sector or other related economic sectors (Whitfield, et al., 2012). Because of MICE events normally occur during off/ low seasons, it reduces seasonality within the host destination; besides successful MICE events can improve the destination image (Munjal, et al., 2014). MICE events usually have a 
large number of attendees; accordingly hosting an exhibition can bring products and services to potential buyers on a large scale. Attending conventions can also expand the partnership with other delegates from the same industry. MICE tourism brings new ideas, knowledge and insights to a country as well as service providers and attendees. It spreads information and knowledge among nations in a wider and faster way. Therefore, since MICE tourism has a tangible economic impact on the hosting destinations, many countries make great efforts in developing their national services, facilities, infrastructure and safety measures to be equivalent with the international standards (Lau, 2009).

\section{2- Stakeholders of MICE Tourism}

Stakeholders of MICE tourism can be divided into three major categories which are: First: Clients: They are the decision makers who hold MICE activities and consist of three main groups: (a) Associations: Non-profit associations, trade or industry organizations formed by their members, (b) Corporations: Companies, entrepreneurial or business organizations and (c) Event planners: Specialized agents hired by organizations to plan their business activities. Second: Suppliers: They are the organizations and enterprises which provide services to MICE activities and they include eleven groups: (a) National Trade Organization which promotes trade for the country, (b) Convention and Visitors Bureau (CVB) that promotes MICE activities to attendees and clients while regulating and supporting MICE clients and other suppliers, (c) Airlines, provide transportation services for attendees of MICE activities, (d) Cruise lines, provide transportation services, accommodation and venues for attendees of MICE activities, (e)Venues, provide spaces where MICE activities can be held (i.e. conference centers, exhibition halls, hotel ballrooms, meeting rooms, universities, heritage sites etc...), (f) Restaurants, provide food and beverage for MICE activities, (g) Accommodations such as hotels, motels and hostels where housing is provided for attendees during MICE events, (h) Professional Convention Organizers (PCO), they help international conventions clients take care of the professional planning, organizing and managing conventions, including bank account set-up, delivery and site selection, (i) Destination Management Companies (DMC), take care of MICE clients when they reach their destination cities, (j) Entertainment, includes performers, venues and performance as a part of MICE program, (k)Technical specialists, provide professional technology or equipment set-up and operating services (i.e. Audio/visual or Lighting), (l) Intermediaries, they are agencies working as middlemen to book various services (i.e. travel agencies). Third: Others: (a) Government and public organizations, agencies and departments at different levels (national), state (provincial), local (municipal) that provide funding and ideas for various MICE activities, (b) Convention industry associations, for example: International Convention and Congress Association (ICCA), Professional Conference Management Association (PCMA) and Meeting Professional Institute (MPI) and (c) Commercial sponsors, they provide funding for MICE activities in return for promoting their brand and products (Lau, 2009).

\section{3- Challenges Facing MICE Tourism}

There are many challenges facing MICE tourism, they can be detailed as follows: (a) Safety and security should be taking into consideration when organizing MICE events. (b) The needs of travelers with special needs (c) Improving services, facilities, venues design and IT developments (Hotel Mule, 2010). (d) Training and education. (e) The lack of data on MICE tourism (i.e. The lack of reliable data on key markets or on how buyers make their purchase decisions, trends in the market; benefits and drawbacks of MICE tourism) (f) Customer satisfaction ( i.e. providing leisure activities, planning more free time during the conferences and meetings, avoiding difficult routes, having relaxation exercises and classes at the venues) and finally (g) Negative environmental impacts (i.e. pollution, greenhouse gases emission, excessive energy consumption, increase in trash and intensify traffic conditions), controlling and minimizing these impacts requires from organizers and attendees to follow rules and regulations as well as to perform their tasks in an environmental/ethical manner (Tsyvinskaya, 2011). 


\section{4- MICE Tourism in Egypt}

MICE industry is considered a major component of business travel and tourism; it grew by $37 \%$ between 2007 and 2014, reaching a 54\% market share (IPK International, 2015, p.9). Within this context, travel for business purposes accounted for 14\% of all international tourist arrivals in 2014 being 158.62 million (WTO, 2015), and 166 million in 2015 (WTO, 2016) and is expected to grow by an average of 5.5\% annually to 2020 (Oxford Business Group, 2011).

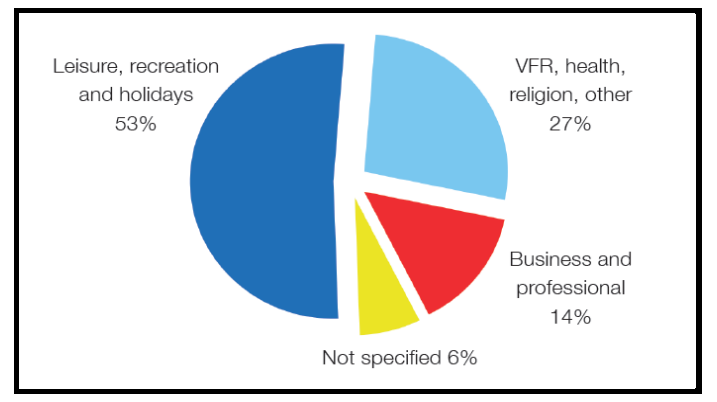

Figure (1): Inbound Tourism by Purpose of Visit, 2014

Source: World Tourism Organization, 2015, p. 5.

During the period from 2008 to 2010, Egypt witnessed a significant recovery for MICE tourism, where many world conferences have been held on its territory such as Davos Economic Forum in Sharm ElSheikh, the National Conference on Population and the African Summit, the World Economic Forum on the Middle East in 2010 (Oxford Business Group, 2011). The total events held in Cairo International Conference Center amounted to (665) events, including (132) international and local conferences and (235) exhibitions and (298) ceremonies and occasions (State Information Service, 2016). Due to the great demand for international conference and exhibitions, $12,000 \mathrm{~m}^{2}$ were added to the Cairo International Conference Center (State Information Service, ND).

Egypt Exposition and Convention Authority (EECA) is one sector of the Ministry of Trade and Industry and is the official authority concerned in organizing the conventions, fairs, events, meetings and exhibitions inside and outside Egypt (Egypt Exposition and Convention Authority, 2016).

Egypt is seeking to attract higher-value tourist segments such as MICE visitors who are luxury shoppers and staying longer than average to finalize and close deals (Blanke \& Chiesa, 2007), as it is full of lavish facilities for MICE tourism; Egypt combines both modern luxury and ancient charm. It can provide high quality facilities and an increasing number of hotel rooms for MICE travelers, Egypt has six international-standard conference and exhibition halls all over the country in Cairo, Alexandria, Luxor and Sharm El Sheikh with about 260.000 rooms, as well as most of the Egyptian tourist cities are full of brand chain hotels that equipped conference rooms especially large-scale conference rooms. Egypt can design and hold activities according to the specified requirements of MICE events in the major cities (i.e. Cairo and Alexandria), or small cities along the Nile (i.e. Luxor and Aswan) or the seaside cities (i.e. Gouna, Marsa Alam, Sharm El Sheikh). Accordingly, culture, seaside and golf are all the key themes for attracting MICE tourism in Egypt, which has a unique potential for MICE tourism, with events that can be organized in its desert sub destinations, halls of its historic areas or palaces (i.e. Karnak Temple, Manial Palace,....etc.). According to The International Congress and Convention Association (ICCA), Egypt is the $69^{\text {th }}$ amid worldwide rankings, with 22 meetings held in 2015, as for Cairo, the capital, the number of meetings is 13. Concerning Africa ranking, Egypt is the third country while Cairo is the fifth city (International Congress and Convention Association, 2016).

From the above mentioned, it can be noted that although Egypt's contribution to the MICE market is growing slowly considerably to other destinations, Egypt can be one of the important destinations in the world for MICE tourism. 


\section{5- Methodology and data collection}

The survey was conducted in two phases; the first was a pilot survey, and the second consisted of actual questionnaire survey based on the feedback from the pilot one.

The survey aims to identify the competitive situation of Egypt as a MICE destination. The target population is tourism and MICE experts in Egypt; A questionnaire was prepared and administered by indepth personal interviewers, E-mails and Facebook Messenger, using a random sample of (70) experts representing tourism and MICE experts in Egypt. Although this sample is not statistically significant because of the difficulty in determining the actual size of the total community-, it is considered sufficient to provide broad indications of major directions, with the aim of this paper. The survey was eventually carried out in September, October and November 2016.

A total of (70) questionnaires were distributed, of them (55) were valid. Data was analyzed by Statistical package for social science (SPSS, V. 15).

\section{6- A Field study applied to a sample of Tourism and MICE experts in Egypt}

\section{6/1- Reliability Analysis}

Table 1: Reliability Coefficient of field study sample

\begin{tabular}{|c|c|c|c|c|}
\hline Population & $\begin{array}{c}\text { Cases } \\
\text { Valid }\end{array}$ & $\begin{array}{c}\text { N of } \\
\text { Items }\end{array}$ & $\begin{array}{c}\text { Reliability } \\
\text { Coefficient (Alpha) }\end{array}$ & $\begin{array}{c}\text { Validity } \\
\text { Coefficient }\end{array}$ \\
\hline Experts & 55 & 64 & 0.886 & $94.13 \%$ \\
\hline
\end{tabular}

* Validity Coefficient $=\sqrt{ }$ Reliability Coefficient

Table (1) indicates that Reliability Coefficient of experts' Responses is $88.6 \%$, and Validity Coefficient, 94.13\%; meaning the consistency and credibility of the experts' sample Responses.

\section{6/2- Descriptive Statistics}

\section{Personal Information}

- Specialization of the Experts

Table 2: Experts' Specialization

\begin{tabular}{|c|l|c|c|c|}
\hline Code & \multicolumn{1}{|c|}{ Specialization } & Frequency & Percent & Rank \\
\hline 1 & - Tourism. & 51 & 92.7 & 1 \\
\hline 1 & - Conference Organizing & 21 & 38.2 & 2 \\
\hline 1 & - Exhibition Organizing. & 10 & 18.2 & 3 \\
\hline
\end{tabular}

* More than one answer is valid.

From table (2), it can be noted that $92.7 \%$ of the experts are tourism experts, while $38.2 \%$ are specialized in organizing conferences and $18.2 \%$ are specialized in organizing exhibitions and fairs as well as many of them have more than one specialty (i.e. leaders in the Ministry of Tourism, Cairo International Conference Center, Sharm El Sheikh International Conference Center, specialized academics in MICE tourism and managers of MICE tourism Departments in travel agencies). 
- Years of Experience.

Table 3: Years of Experience

\begin{tabular}{|c|c|c|c|c|}
\hline Code & Years of experience & Frequency & Percent & Mean \\
\hline 1 & - From 20 years to 30 years. & 43 & 78.2 & \multirow{3}{*}{1.33} \\
\hline 2 & - More than 30 years to 40 years. & 6 & 10.9 & \\
\hline 3 & - More than 40 years. & 6 & 10.9 & \\
\hline 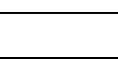 & $\begin{array}{rr} & \text { Total } \\
\end{array}$ & 55 & 100 & \\
\hline
\end{tabular}

From table (3) it is seen that majority of experts (78.2\%) have 20 to 30 year experience in the fields of tourism and organizing conferences, exhibitions and fairs.

\section{The Competitive Situation of Egypt as a MICE Destination}

- Diversity of Egyptian Tourism Product (Experts' Opinion)

Table 4: Experts' Agreement on the Diversity of Egyptian Tourism Product

\begin{tabular}{|c|c|c|c|c|c|c|}
\hline Code & Response & Frequency & Percent & Mean & St.dev. & C.V. \\
\hline 5 & - Strongly Agree. & 18 & 32.7 & \multirow{5}{*}{3.71} & \multirow{5}{*}{1.133} & \multirow{5}{*}{$30.5 \%$} \\
\hline 4 & - Agree. & 12 & 21.8 & & & \\
\hline 3 & - Somewhat Agree. & 18 & 32.7 & & & \\
\hline 2 & - Disagree. & 5 & 9.1 & & & \\
\hline \multirow[t]{2}{*}{1} & - Strongly disagree. & 2 & 3.6 & & & \\
\hline & Total & 55 & 100 & & & \\
\hline
\end{tabular}

Table (4) shows a diversity of the Egyptian tourism product; with a mean of (3.71) and a C.V. of (30.5\%). It is seen that $(54.5 \%)$ of the sample agreed and strongly agreed on the diversity of the Egyptian tourism product, $(32.7 \%)$ of the sample agreed to somewhat, while (12.7\%) disagreed and strongly disagreed.

- MICE Tourism is a Component of the Egyptian Tourism Product

Table 5: MICE Tourism is a Component of the Egyptian Tourism Product

\begin{tabular}{|c|c|c|c|c|c|c|}
\hline Code & Response & Frequency & Percent & Mean & St.dev. & C.V. \\
\hline 5 & - Strongly Agree. & 10 & 18.2 & \multirow{5}{*}{3.40} & \multirow{5}{*}{0.915} & \multirow{5}{*}{$26.91 \%$} \\
\hline 4 & - Agree. & 8 & 14.5 & & & \\
\hline 3 & - Somewhat Agree. & 31 & 56.4 & & & \\
\hline 2 & - Disagree. & 6 & 10.9 & & & \\
\hline \multirow[t]{2}{*}{1} & - Strongly disagree. & 0 & 0.0 & & & \\
\hline & Total & 55 & 100 & & & \\
\hline
\end{tabular}


From table (5), the sample opinion is in the direction of agreeing somewhat on considering MICE tourism as a component of the Egyptian tourism product; with a mean of (3.4) and a C.V. of (26.91\%).

It is also revealed that $(56.4 \%)$ of the sample agreed somewhat on considering MICE tourism as a component of the Egyptian tourism product, (18.2\%) strongly agreed, (14.5\%) agreed, while (10.9\%) disagreed.

\section{- Benefits of MICE Tourism to the Egyptian Destination}

Table 6: Experts' Agreement that MICE Tourism will benefit the Egyptian Destination

\begin{tabular}{|c|c|c|c|c|c|c|}
\hline Code & Response & Frequency & Percent & Mean & St.dev. & C.V. \\
\hline 5 & - Strongly Agree. & 39 & 70.9 & \multirow{5}{*}{4.56} & \multirow{5}{*}{0.788} & \multirow{5}{*}{$17.28 \%$} \\
\hline 4 & - Agree. & 10 & 18.2 & & & \\
\hline 3 & - Somewhat Agree. & 4 & 7.3 & & & \\
\hline 2 & - Disagree. & 2 & 3.6 & & & \\
\hline \multirow[t]{2}{*}{1} & - Strongly disagree. & 0 & 0.0 & & & \\
\hline & Total & 55 & 100 & & & \\
\hline
\end{tabular}

From table (6), experts strongly agreed on the benefits of MICE tourism to the Egyptian destination concerning the number of tourists and revenues, with a mean of (4.56) and a coefficient of variance of (17.28\%); the lowest dispersion of experts opinion. About (89.1\%) agreed and strongly agreed, (7.3\%) of the sample agreed somewhat, while (3.6\%) disagreed.

\section{- Egyptian Resources for MICE Tourism}

Table 7: Facilities for MICE Tourism in Egypt

\begin{tabular}{|c|l|c|c|c|}
\hline Code & \multicolumn{1}{|c|}{ Facilities/ Resources } & Frequency & Percent & Rank \\
\hline 1 & - Conference centers. & 39 & 70.9 & 2 \\
\hline 1 & - Appropriate Infrastructure. & 17 & 30.9 & 8 \\
\hline 1 & - Safety and Security. & 16 & 29.1 & 9 \\
\hline 1 & - Egyptian reputation among other MICE destinations. & 10 & 18.2 & 11 \\
\hline 1 & - Egyptian hospitality. & 29 & 52.7 & $4 /$ \\
\hline 1 & - Commercial Traffic in Egypt. & 14 & 25.5 & 10 \\
\hline 1 & - Variety of accommodation with suitable prices. & 33 & 60 & 3 \\
\hline 1 & - Availability of holding exhibitions. & 24 & 43.6 & 6 \\
\hline 1 & - Accessibility. & 29 & 52.7 & 4 \\
\hline 1 & \begin{tabular}{l} 
facilities. \\
\hline 1
\end{tabular} & - Availability of business tourism services. & 85.5 & 1 \\
\hline
\end{tabular}

* More than one answer is valid. 
From table (7), It is seen $85.5 \%$ see that tourist attractions and entertainment facilities all over Egypt can make it more attractive for MICE tourists (i.e. Cairo, Alexandria, Gouna, Marsa Alam, Sharm El Sheikh, Fayoum, Siwa... etc.) as these services can be used pre and post-convention tours and convention tours included in the program. Egypt has many conference centers and venues can be easily reached by ports and airports, has a variety of accommodation with suitable prices for the increasing number of delegates as stated by $70.9 \%-60 \%$ of respondents. Egyptian hospitality attracts tourists all over the world; (52.7\%).

\section{- Egypt's Strengths as a MICE Destination}

Table 8: Strengths for MICE Tourism in Egypt

\begin{tabular}{|c|l|c|c|c|}
\hline Code & \multicolumn{1}{|c|}{ Strengths } & Frequency & Percent & Rank \\
\hline 1 & - Facilities for incentive tourism in Egypt. & 28 & 50.9 & 7 \\
\hline 1 & $\begin{array}{l}\text { - High quality of audio, video and interpreting } \\
\text { services. }\end{array}$ & 26 & 47.3 & 9 \\
\hline 1 & - Airports capacity. & 21 & 38.2 & 10 \\
\hline 1 & - Capacity of ports. & 12 & 21.8 & 12 \\
\hline 1 & - Moderate temperature and climate all the year. & 45 & 81.8 & 2 \\
\hline 1 & $\begin{array}{l}\text { - Sufficient number of five star hotels with skilled } \\
\text { staff. }\end{array}$ & 41 & 74.5 & 3 \\
\hline 1 & - Specialized workforce in MICE tourism. & 20 & 36.4 & 11 \\
\hline 1 & - Sufficient number of conference centers. & 29 & 52.7 & 6 \\
\hline 1 & - Many venues for exhibitions. & 27 & 49.1 & 8 \\
\hline 1 & - Proximity to Europe and Arab countries. & 37 & 67.3 & 4 \\
\hline 1 & - Incredible beaches, deserts and heritage sites. & 47 & 85.5 & 1 \\
\hline 1 & - Competitive prices. & 35 & 63.6 & 5 \\
\hline 1 & - Others. & 0 & 0.0 & 13 \\
\hline
\end{tabular}

* More than one answer is valid.

Table (8) shows Egypt's strengths in MICE tourism, as (85.5\%) of the sample stated that Egypt has incredible beaches, deserts and world heritage sites which make Egypt more interesting for MICE organizers, $(81.1 \%)$ stated that moderate climate all the year is a competitive advantage for Egypt, $(74.5 \%)$ indicated that there is a sufficient number of five star hotels with skilled staff; another strength point for Egypt is its proximity to Europe and Arab countries (67.3\%), beside competitive prices (63.6\%), while $(52.7 \%)$ of the sample stressed on the sufficient number of conference centers, (50.9\%) pointed to the good facilities for incentive tourism in Egypt, (49.1\%) mentioned that Egypt has many venues for exhibitions, $(47.3 \%)$ considered high quality of audio, video and interpreting services as important points for Egypt. 
- Egypt's Weaknesses as a MICE Destination

Table 9: Weaknesses of MICE Tourism in Egypt

\begin{tabular}{|c|c|c|c|c|}
\hline Code & Weaknesses & Frequency & Percent & Rank \\
\hline 1 & $\begin{array}{l}\text { - Egypt is still not known as a leading MICE } \\
\text { destination. }\end{array}$ & 33 & 60 & 2 \\
\hline 1 & $\begin{array}{l}\text { - Poor marketing efforts of Egypt as a MICE } \\
\text { destination. }\end{array}$ & 45 & 81.8 & 1 \\
\hline 1 & - Pollution. & 29 & 52.7 & 4 \\
\hline 1 & - Transportation must be developed. & 29 & 52.7 & 4/ \\
\hline 1 & $\begin{array}{l}\text { - Small travel agencies cannot organize mass } \\
\text { events. }\end{array}$ & 24 & 43.6 & 6 \\
\hline 1 & - Insufficient statistics of MICE tourism in Egypt. & 21 & 38.2 & 7 \\
\hline 1 & $\begin{array}{l}\text { - Lack of awareness of the importance of MICE } \\
\text { tourism. }\end{array}$ & 33 & 60 & $2 /$ \\
\hline 1 & - Others. & 12 & 21.8 & 8 \\
\hline
\end{tabular}

* More than one answer is valid.

Table (9) illustrates Egypt's weaknesses as a MICE destination, (81.1\%) of the sample agreed that marketing efforts for Egypt as a MICE destination are ineffective, also Egypt is still not known as a leading MICE destination (60\%); the findings showed also lack of awareness of the importance of MICE tourism (60\%); since there is insufficient number of specialized MICE companies. Pollution and transportation problems must be solved (52.7\%), most of the Egyptian travel agencies are small and cannot organize mega events by $(43.6 \%)$. Of weakness points, is the insufficient statistics about MICE tourism in Egypt $(38.2 \%)$, while $(21.8 \%)$ of the sample mentioned other weaknesses such as: The absence of an independent authority concerning MICE tourism, internet and communication problems in some areas in Egypt, instability in the Middle East, traffic problems and continuous change in the body responsible for Cairo International Conference Center as well as the Exhibitions Authority.

\section{- Egypt's Opportunities as a MICE Destination}

Table 10: Opportunities for MICE Tourism in Egypt

\begin{tabular}{|c|l|c|c|c|}
\hline Code & \multicolumn{1}{|c|}{ Opportunities } & Frequency & Percent & Rank \\
\hline 1 & - New conference centers. & 33 & 60 & 2 \\
\hline 1 & - Egypt has a lot more capacity to be utilized. & 51 & 92.7 & 1 \\
\hline 1 & $\begin{array}{l}\text { - Expansions at airports/ Developing } \\
\text { infrastructure and superstructure. }\end{array}$ & 26 & 47.3 & 3 \\
\hline 1 & - Others. & 8 & 14.5 & 4 \\
\hline
\end{tabular}

* More than one answer is valid.

Table (10) illustrates the opportunities for MICE Tourism in Egypt. It could be detailed as follows (92.2\%) of the sample indicated that Egypt has a lot more capacity to be utilized, (60\%) mentioned new conference 
centers, $(47.3 \%)$ pointed to expansions at airports and developing infrastructure and superstructure, while $(14.5 \%)$ of the sample mentioned other opportunities which are: Increasing investment opportunities in new Suez Canal, increasing number of graduates from faculties of tourism and hotels qualified to work in MICE tourism as well as increasing awareness of the significance of MICE tourism among employees in the tourism sector.

\section{- Egypt's Threats as a MICE Destination}

Table 11: Threats Facing MICE Tourism in Egypt

\begin{tabular}{|c|l|c|c|c|}
\hline Code & \multicolumn{1}{|c|}{ Threats } & Frequency & Percent & Rank \\
\hline 1 & - High taxes and fees at airports and ports. & 16 & 29.1 & 4 \\
\hline 1 & - Increasing competition. & 43 & 78.2 & 1 \\
\hline 1 & - Poor transportation infrastructure. & 18 & 32.7 & 3 \\
\hline 1 & - Instability in the Middle East. & 39 & 70.9 & 2 \\
\hline 1 & - Others. & 2 & 3.6 & 5 \\
\hline
\end{tabular}

* More than one answer is valid.

From table (11), it is apparent that there are many threats facing MICE tourism in Egypt. Thus, (78.2\%) of the sample consider the increasing competition with a lot of counties in the Arab Region; (70.9\%) of the sample believed that terrorism, war and instability in the Middle East are major threats. Finally (3.6\%) of the sample pointed to that organizing conferences and exhibitions by non- specialized entities might affect negatively the image of MICE tourism in Egypt.

\section{- Procedures have been taken to Improve MICE Tourism in Egypt (Experts' View)}

Table 12: Procedures have been taken to improve MICE Tourism in Egypt

\begin{tabular}{|c|l|c|c|c|}
\hline Code & \multicolumn{1}{|c|}{ Procedures } & Frequency & Percent & Rank \\
\hline 1 & - Developing infrastructure and superstructure. & 28 & 50.9 & 1 \\
\hline 1 & - Cooperation between public and private sector. & 20 & 36.3 & 4 \\
\hline 1 & - Support of tourism authorities to this trend. & 25 & 45.4 & 3 \\
\hline 1 & $\begin{array}{l}\text { - Improving transportation networks between and } \\
\text { inside cities. }\end{array}$ & 27 & 49.1 & 2 \\
\hline 1 & - Others. & 3 & 5.4 & 5 \\
\hline
\end{tabular}

* More than one answer is valid.

The findings of table (12) shed light on the procedures taken to improve MICE tourism in Egypt. It could be detailed as follows: $(50.9 \%)$ of the sample indicated that there has been development in the infrastructure and superstructure, $(49.1 \%)$ mentioned the improvements in transportation networks between and inside cities, (5.4\%) of the sample stressed on the individual efforts of MICE tourism companies. 
- Procedures must be taken to improve MICE tourism in Egypt (Experts' view)

Table 13: Procedures that must be taken to improve MICE Tourism in Egypt

\begin{tabular}{|c|l|c|c|c|}
\hline Code & \multicolumn{1}{|c|}{ Procedures } & Frequency & Percent & Rank \\
\hline 1 & $\begin{array}{l}\text { - Providing training courses concerning MICE } \\
\text { tourism (universities, institutions... etc.). }\end{array}$ & 40 & 72.7 & 3 \\
\hline 1 & $\begin{array}{l}- \text { Raising awareness of the importance of MICE } \\
\text { tourism. }\end{array}$ & 49 & 89.1 & 1 \\
\hline 1 & - Studying competitors' strategies, & 39 & 70.9 & 4 \\
\hline 1 & $\begin{array}{l}\text { - Develop a unified policy to prepare Egypt for } \\
\text { MICE tourism \& Analyzing deficiencies of } \\
\text { MICE tourism in Egypt. }\end{array}$ & 45 & 81.8 & 2 \\
\hline 1 & - Others. & 8 & 14.5 & 5 \\
\hline
\end{tabular}

* More than one answer is valid.

From table (13); it is concluded that, there are many procedures to improve MICE tourism in Egypt such as raising awareness of the importance of MICE tourism to Egypt (89.1\%), developing a unified policy to prepare Egypt for MICE tourism and analyzing deficiencies of MICE tourism in Egypt (81.1\%), providing training courses concerning MICE tourism (universities, institutions......etc.) (72.7\%), studying competitors' strategies and preparing suitable plans $(70.9 \%)$,while (14.5\%) mentioned other procedures which are: Marketing MICE tourism through the Ministry of Tourism, focusing on e-marketing, applying incentive system for successful MICE tourism companies, raising awareness of the importance of MICE tourism to encourage tourism companies to adopt this significance type of tourism, activating the role of Cairo International Conference Center and re-affiliating Cairo International Conference Center to the Ministry of Tourism managerially, financially and technically.

\section{Field Study Results}

The field study resulted as following:

1- There is diversity in the Egyptian tourism product including MICE tourism as a component of that product.

2- Experts strongly agree on the benefits of MICE tourism to Egyptian destination, in terms of tourist arrivals and tourism revenues.

3- Egyptian facilities for MICE tourism are represented in tourist attractions, leisure tourism services, conference centers and halls, variety of accommodation at suitable prices, accessibility, Egyptian hospitality and the availability of holding exhibitions and fairs.

4- The strengths of Egypt as a MICE destination can be detailed as follows: The diversity of attractions such as beaches, deserts and heritage sites - moderate climate all the year, a sufficient number of five star hotels with skilled staff - Proximity to Europe and Arab countries - Competitive prices compared to other countries in the same region - a sufficient number of conference centers - Great potential for incentive tourism as well as many venues for holding exhibitions.

5- Egypt's weaknesses as a MICE destination are as follows: marketing efforts are ineffective, Egypt is still not known as a leading MICE destination - Egyptian tourism companies are not aware of the importance of MICE tourism, accordingly few tourism companies are specialized in this type of tourism. 
6- Opportunities for MICE Tourism in Egypt could be detailed as follows: the investment opportunities in the new Suez Canal, increasing number of qualified graduates from faculties of tourism and hotels to work in organizing conferences, exhibitions and incentive programs.

7- There are many threats facing MICE tourism in Egypt which are: increasing competition with many counties in the Arab Region, terrorism and instability in the Middle East, organizing conferences and exhibitions by non- specialized entities.

\section{Recommendations}

Based on the results, recommendations could be directed to the Egyptian Government, Ministry of Tourism, Egyptian Tourism Authority, Egyptian Travel Agents Association, Travel Agencies, Faculties of Tourism and Hotels and Conference Centers; as follows:

\section{- Recommendations for the Egyptian Government}

1- Egyptian government should support the trend towards marketing Egypt as a MICE tourism destination.

2- Re-affiliating Cairo International Conference Center to the Ministry of Tourism administratively, technically and financially, as well as to the Exhibitions Authority.

3- Implementing sustainable strategies to protect Egyptian environment to be more attractive as a MICE destination.

4- Solving traffic problems by improving transportation networks beside establishing new roads.

5- Investment projects of the new Suez Canal should include establishing an international conference center with exhibition halls.

6- Developing a unified policy at the state level to prepare Egypt for MICE tourism and analyzing the obstacles to applying this type of tourism.

\section{- Recommendations for the Egyptian Ministry of Tourism}

7- Granting incentives and facilities to successful MICE tourism companies to encourage other tourism companies to diversify their programs.

\section{- Recommendations for the Egyptian Tourism Authority}

8- Marketing strategies should focus on the diversification of the Egyptian tourism product including cultural, recreational, medical, special events, rural, agricultural, diving, conferences, exhibitions, incentives and other types of tourism to attract various market segments and overcome the current stagnation of tourist movement. .

9- Launching marketing to correct the image of the Egyptian destination and focusing on the quiet areas away from any political or security disturbances (i.e. Marsa Alam, Siwa,...etc.).

10- Promoting Egypt as a MICE destination through participating in international and regional conferences concerning incentive, conference and exhibition tourism such as the Gulf Incentive, Business Travel \& Meeting \& Exhibition (GIBTM).

11- Launching promotional campaigns all over the world to create a new brand of the Egyptian destination as a MICE tourism destination, and through Familiarization trips and awareness programs.

\section{- Recommendations for the Egyptian Travel Agents Association}

12- Organizing training courses for tourism managers and employees in Egyptian tourist companies to qualify them as a skilled workforce.

13- Raising awareness about the importance of diversifying tourist programs and the benefits of each type of tourism.

14- Organizing workshops for tourism companies about how to organize successful MICE events in which Egyptian or foreigner specialists of MICE tourism will lecture.

15- Holding seminars about competitors' experiences in MICE tourism, especially the experience of the United Arab Emirates as well as focusing on the benefits of this type of tourism.

\section{- Recommendations for Travel Agencies in Egypt}

16- Promoting non utilized tourist sites in Egypt for incentive programs and conferences by organizing creative tourism programs not implemented before to attract incentive houses and MICE organizers 


\section{- Recommendations for Faculties of Tourism and Hotels}

17- Developing the tourism education and providing special courses about new trend tourism such as conference, incentive and exhibition tourism.

18- Faculties of tourism and hotel management should organize training courses for employees in tourism companies to qualify them in MICE tourism.

\section{- Recommendations for the Conference Centers in Egypt}

19- Maintenance of audio and video equipments.

20- Translation should be available at all conference centers and halls.

21- Activating the role of international conference centers by implementing marketing strategies.

\section{References}

Blanke, J. and Chiesa, T.,(2007):The Travel and Tourism Competitiveness Report: Furthering the Process of Economic Development, World Economic Forum, Geneva- Switzerland.

Egypt Exposition and Convention Authority (2016): About Egypt Expo\& Convention Authority (EECA), Cairo- Egypt, In: http://www.eeca.gov.eg/eeca.html , Last access 11/11/2016.

Hotel Mule (2015): Conference tourism-MICE market and business tourism, E Travel Week, 15 may, In: $\quad$ https://etravelweek.com/imported/conference-tourism-\%E2\%80\%93-mice-market-andbusiness-tourism , Last access 12/11/2016.

International Congress and Convention Association (2016): The International Association Meetings Market 2015, ICCA Statistics Report, ICCA Publishing, Amsterdam, Netherlands.

Khan, M., (2015): Mice Tourism, International Journal of Multidisciplinary Research and Development, Volume 2, Issue 4, Delhi, India, April.

Lau, C., (2009): Tourism and Hospitality Studies Meetings, Incentives, Conventions and Exhibitions (MICE): Manual on Elective I, Government of the Hong Kong Special Administrative Region, Hong Kong.

Lin, C., and Chen, J., (2014):The Impact of Societal and Social Innovation: A Case Based Approach, Springer, Singapore.

Munjal, P.; Kolli, R.; Sharma, R.; Sharma, A.; Grover, M.; Kumar, P. and Singh, S., (2014): MICE Tourism in India, 2009-10, National Council of Applied Economic Research, Ministry of Tourism, Government of India, New Delhi- India.

Ratajczak-Mrozek, M., (2014): Cooperation, Innovations and Knowledge in MICE Tourist Product Perception, 5th EMAC Regional Conference Marketing Theory Challenges in Emerging Markets, Publishing House of the University of Economics, katowice- Poland, September 2426.

Smith, J. and Stewart, S., (2014): Cambridge international AS and A level: Travel and Tourism, Cambridge University press, Cambridge- UK.

State Information Service (2016): Tourism in Egypt, Cairo- Egypt, 15 May, In: http://www.sis.gov.eg/Story/1042?lang=en-us, Last access 11/11/2016.

State Information Service (ND): Conference and Exhibition Tourism, Cairo- Egypt, In: http://www.sis.gov.eg/section/4844/4844, Last Access 27/11/2016.

Oxford Business Group (2011): The Report :Egypt 2011, London- UK.

Tsyvinskaya, A.,(2011): Russian Outbound Mice Tourism: Demand and Concept, Bachelor's Thesis, Degree Program in Tourism, Hospitality Management, Unit of Tourism, Saimaa University of Applied Sciences, Lappeenranta- Finland. 
Wan, YKP,(2011): Assessing the strengths and weaknesses of Macao as an attractive meeting and convention destination: perspectives of key informants, Journal of Convention \& Event Tourism, Issue 2, Volume 12, UK.

Whitfield, J., Dioko, L., Webber, D., and Zhang, L., (2012): Attracting Convention and Exhibition Attendance to Complex Mice Venues: Emerging Data from Macao, International Journal of Tourism Research, John Wiley \& Sons, Inc.

$$
\text { سياحة الـ MICE في مصر: الفرص والتحديات }
$$

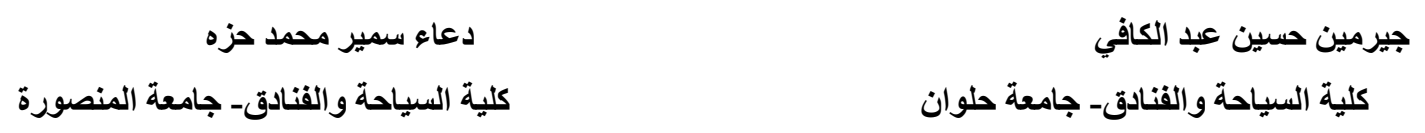

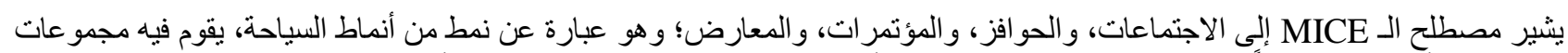

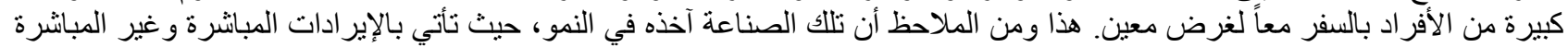

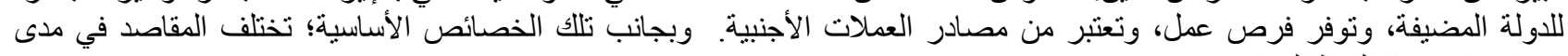
استفادتها من هذا النمط السباحي.

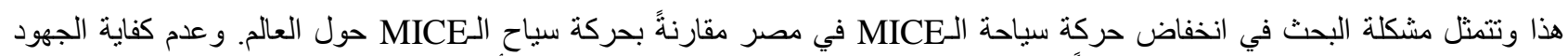

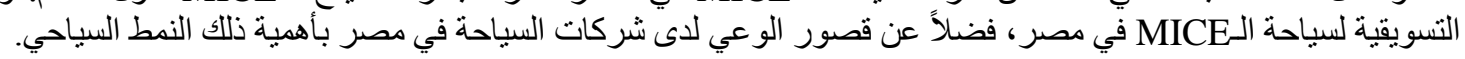

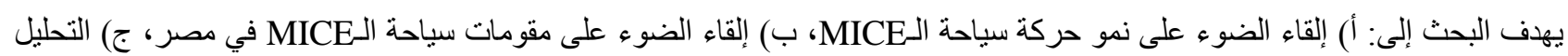

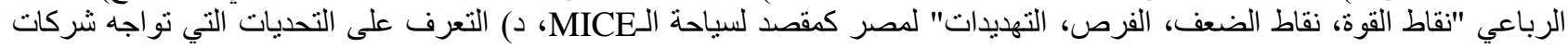

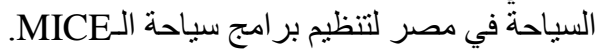

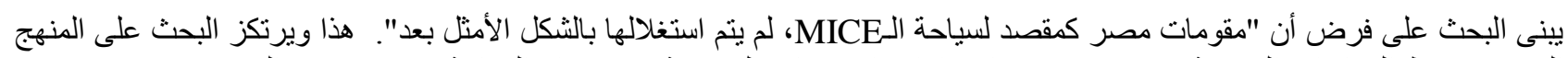

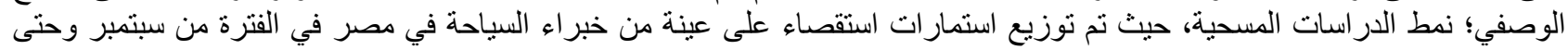

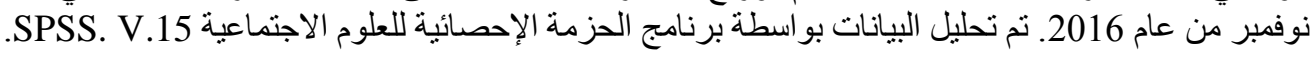

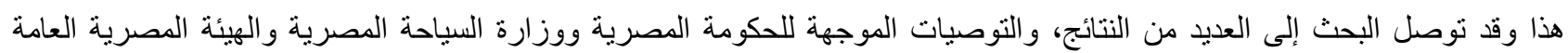

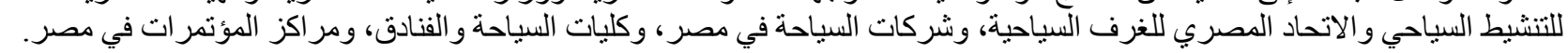

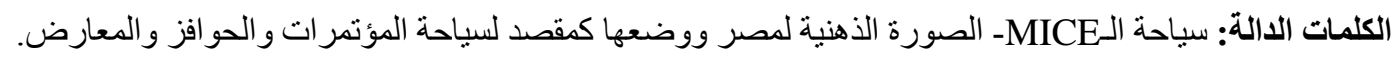

